\title{
Photoperiodic control of prolactin secretion in the goat
}

\author{
Yuji Mori*, Keiichiro MaEda, Toru Sawasaki \\ and Yasuhiko KaNo \\ Stock Farm, Faculty of Agriculture, University of Tokyo, \\ Itvama, Ibaraki 319-02
}

\begin{abstract}
Summary. Effects of photoperiods on prolactin (PRL) secretion were investigated by keeping female Saanen goats under artificial long days (16L8D) or short days (8L16D). Exposure to experimental photoperiods was started in December 1980 (day 0) and continued for about a year. Plasma PRL of the long-day group was elevated to the levels much higher than those of the short-day group. Effects of photoperiods on the diurnal fluctuation of plasma PRL were also evident on selected days when blood samples were taken at short intervals (day 24 and 118): being enhanced under long days and damped under short days. In July and August 1981, a marked elevation of PRL levels was noted in both groups, probably due to high ambient tem. perature which might have masked the effects of short-days. In the long-day group, goats were anovulatory when PRL levels were high (day 78-148), however, by day 200 they resumed estrous cyclicity spontaneously in association with the decrease in plasma PRL, sug. gesting that there might be an intrinsic mechanism which gradually increases the critical day lengths.
\end{abstract}

(Japan. J. Anim. Reprod., 31, 9-15, 1985)

\section{Introduction}

Prolactin (PRL) secretion in sheep ${ }^{1,2)}$ and goats $^{3-5)}$ is known to show a marked seasonal fluctuation: peripheral PRL concentrations are high in the spring and summar (corresponding with seasonal anestrus) and low in the autumn and winter (breeding season). Contribution of the daylength to this annual PRL profile has been well established in sheep; artificial reversal of annual change in daylength resulted in an inverted annual pattern of PRL secretion ${ }^{\text {) }}$, and repeated exposure to long days and short days resulted in cyclical changes in plasma PRL concentrations according to the photoperiods $^{\text {) }}$. In addition to the photoperiod ambient temperature ${ }^{5,8)}$ may affect

* Present address: Laboratory of Veterinary Re. production, Faculty of Agriculture, Tokyo University of Agriculture and Technology, Fuchu, Tokyo 183. seasonal profile of PRL secretion in sheep.

The purpose of the present study was first to evaluate the effect of photoperiod on PRL secretion in female goats. Secondly, since a line of evidence suggests that hyperprolactinemia causes hypogonadism in women $^{9,10,11)}$, ewes ${ }^{12,13)}$, the relationship between plasma PRL levels and reproductive activities was investigated in the goats living under different artificial lighting conditions, of which estrous cyclicity has already been reported $^{14)}$.

\section{Materials and Methods}

\section{Animals:}

Female Saanen goats which had been recurring normal estrous cycles were divided into long-day group $(n=8)$ and short-day group $(n=5)$. The animals and experimental conditions were the same as those previously described $^{14)}$. Exposure of the goats to arti- 
ficial long days (16h light and $8 \mathrm{~h}$ dark; 16L8D) was commenced on December 4, 1980 (day 0 ) and continued for about a year. The goats of the short-day group were kept under natural short days until day 63 (Feb. 3) and onwards under the artificial short days (8L16D); except for one animal which remained under natural daylights. Two goats of the long-day group were subjected to the short days after day 55. Changes in outdoor and indoor temperatures were continuously recorded throughout the experimental period.

Collection of blood samples:

In addition to the twice weekly blood sampling throughout the experiment ${ }^{14)}$, on day 42 and day 118 more intensive sampling was performed at $2 \mathrm{~h}$ intervals for $24 \mathrm{~h}$ by puncturing the jugular vein aiming to investigate the diurnal pattern of PRL secretion under respective lighting regimen. On each occasion particular care was taken not to disturb the animals which remained in their normal pens. Local and faint lighting method was used to aid blood sampling during the dark period of each $24 \mathrm{~h}$ cycle. Plasma was immediately separated by centrifugation and stored at $-20 \mathrm{C}$ until assayed for PRL. Hormone assay:

Plasma PRL concentrations were assayed for the $24 \mathrm{~h}$ blood samples and selected biweekly samples by the double-antibody radioimmunoassay for goat PRL established by JoHKE et al..$^{3)}$ with some modification as described below. Highly purified ovine PRL (Li-sheep PRL) was iodinated with ${ }^{125 I}$ (New England Nuclear Co., USA) by the lactoperoxidase method ${ }^{13)}$. Specific activity of iodinated PRL was $94.6 \mu \mathrm{Ci} / \mu \mathrm{g}$. Samples of $20 \mu l$ goat plasma was diluted with $80 \mu l$ of phosphate buffered saline ( $\mathrm{pH} 7.4,0.01 \mathrm{M})$ containing $1 \%$ bovine serum albumin (PBSBSA) and incubated with $100 \mu l$ of ${ }^{123}$ I-PRL $(27,000 \mathrm{dpm}$ in PBS-BSA) and $100 \mu l$ of antibovine PRL guinea pig serum $(1: 150,000$ in PBS containing $0.5 \%$ normal guinea pig serum and $0.05 \mathrm{M}$ EDTA) which was developed and characterized by JoHKE ${ }^{18)}$. After $24 \mathrm{~h}$ incubation at $4 \mathrm{C}, 200 \mu \mathrm{l}$ of anti-guinea pig gamma globulin caprine serum developed

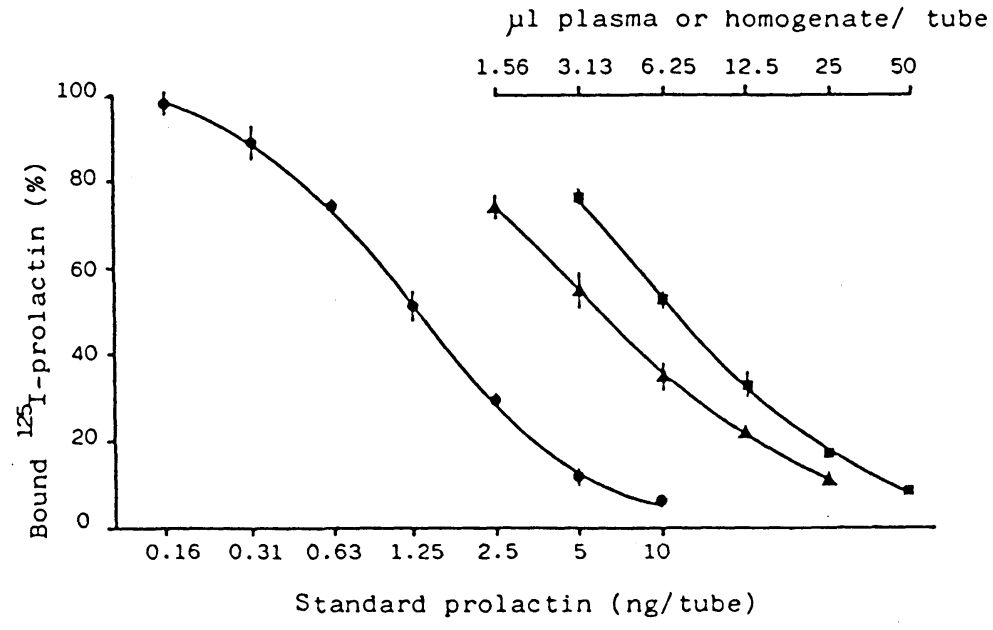

Fig. 1. Displacement curves for serial dilutions of pooled goat plasma ( $\mathbf{m}$ ) and a goat pituitary homogenate $(\boldsymbol{\Lambda})$ demonstrating parallelisms with the displacement curve of stand. ard prolactin (NIH PS.8, ๑). Each point represents the mean \pm SD $(n=3)$. 
in our laboratory (1:30 in PBS) was added. Following second incubation for $24 \mathrm{~h}$ at $4 \mathrm{C}$ the mixture was centrifuged for $30 \mathrm{~min}$ at $4 \mathrm{C}$ and the radioactivity of precipitate was counted. The specificity of the assay was validated by comparing displacement curves for serial dilutions of pooled goat plasma and a goat pituitary homogenate with the displacement curve of the standard ovine prolactin, NIH P-S8; the 3 curvès did not depart from parallelism $(2 \times 3$ points design, $P>0.05)$ as shown in Fig. 1 , and the interference by endogenous PRL in caprine second antiserum was negligible. To ascertain the accuracy of the assay various amounts of PRL were added to a pooled goat plasma. They were assayed in triplicate by the radioimmunoassay as described above, and a satisfactory correlation $(r=0.998, P<$ $0.01, n=12)$ was obtained between added $(x)$ and recovered PRL $(y)(y=1.07 x+0.07)$. All samples from one animal were assayed in a single assay. The limit of detection (95\% confidence limits of buffer control) averaged $3.9 \mathrm{ng} / \mathrm{ml}$ for $20 \mu l$ plasma. The intra- and inter-assay coefficients of variation were 7.0\% ( $n=6)$ and $12.5 \%(n=5)$, respectively.

Assessment of estrous cyclicity:

Percentages of the goats recurring estrous cycles under either long days or short days were calculated by dividing the observed number of ovulation by the expected number of ovulation (one ovulation per animal per three weeks); the occurrence of ovulation was estimated from plasma progesterone profiles of these goats which have already been reported ${ }^{14)}$.

\section{Statistical analysis:}

Results were expressed as mean \pm SEM and Student's $t$ test or Cochran-Cox test was used to determine the significance of difference between the means.

\section{Results}

Plasma PRL concentrations of the long-day goats tended to stay in higher levels than those of short-day group as shown in Fig. 2, and were significantly higher on days between 78 and 148; besides this period a significant difference was obtained only occasionally on day 247 and day 320. Remarkable elevations in plasma PRL with similar amplitude $(>80 \mathrm{ng} / \mathrm{ml}$ ) and pattern in both groups were observed during the summer period between day 218 (Jul. 10) and day 261 (Aug. 22) when ambient temperature exceeded $27 \mathrm{C}$ at the time of blood sampling.

Figure 3 shows diurnal patterns of plasma PRL on day 42 (Jan. 15) and day 118 (Mar. 31). On day 42 the long-day goats exhibited high plasma PRL levels with marked nocturnal elevation (Fig. $3 \mathrm{~A}$; mean PRL level on that day was $47.0 \pm 6.7 \mathrm{ng} / \mathrm{ml}$ ), while the

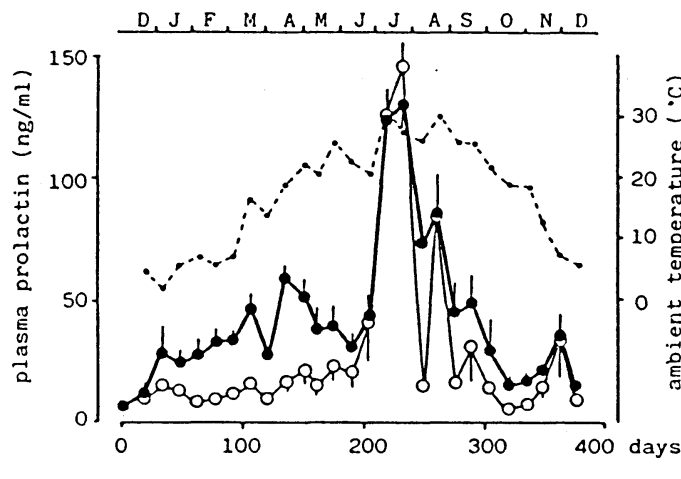

Fig. 2. Plasma prolactin concentrations (mean \pm SEM) in female Saanen goats which were subjected to artificial long days of $16 \mathrm{~L} 8 \mathrm{D}$ (closed circle, $n=5$ ) and short days of $8 \mathrm{~L} 16 \mathrm{D}$ (open circle, $n=4$ ). Exposure to $16 \mathrm{~L} 8 \mathrm{D}$ was commenced on day 0 . Changes in ambient temperature recorded at the time of blood sampling (around 10:00 h) are presented as the broken line. 

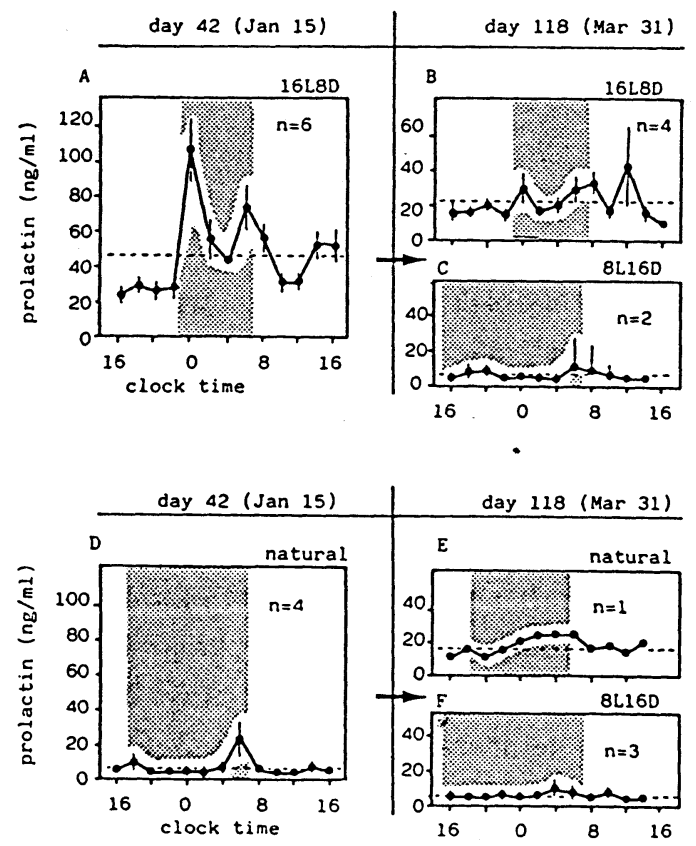

Fig. 3. Diurnal patterns of plasma prolactin concentrations (mean \pm SEM, or \pm range $(C)$ ) in the goats staying under different photoperiodic conditions. Blood sampling at $2 \mathrm{~h}$ intervals for $24 \mathrm{~h}$ was performed on day 42 (left panels) and day 118 (right panels). Shaded area shows the dark phase and the horizontal broken line indicates the mean prolactin level for the group on that day. A: 42 nd day under $16 \mathrm{~L} 8 \mathrm{D}$, B: 118 th day under $16 \mathrm{~L} 8 \mathrm{D}$. C: 63 rd day after transferred from $16 \mathrm{~L} 8 \mathrm{D}$ to $8 \mathrm{~L} 16 \mathrm{D}$. D, E: under natural photoperiod on Jan. 15 and Mar. 31. F: 63rd day after transferred from out. door to $8 \mathrm{~L} 16 \mathrm{D}$.

goats under natural short days showed low PRL secretion ( $D ; 6.7 \pm 0.5 \mathrm{ng} / \mathrm{ml}$ ). On day 118 plasma PRL were relatively high in the long-day goats $(\mathrm{B} ; 22.3 \pm 2.7 \mathrm{ng} / \mathrm{ml}$ ), while PRL levels were very low in the goats which had been transferred from long days to short days $(C ; 5.7 \pm 0.8 \mathrm{ng} / \mathrm{ml})$ as in the goats continuously exposed to short days $(\mathrm{F} ; 6.7 \pm$ $1.0 \mathrm{ng} / \mathrm{ml}$ ). The goat staying outdoor showed higher PRL levels on day 118 (E; $16.4 \pm 1.3$ $\mathrm{ng} / \mathrm{ml}$ ) than did on day 42 (D).

Figure 4 shows effects of long days on estrous

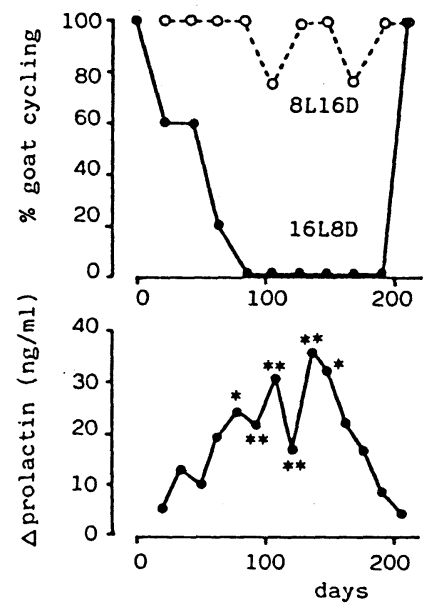

Fig. 4. Effects of photoperiod on estrous cyclicity and prolactin secretion in the goat. A) Percentages of the goats recurring estrous cycles under long days ( $16 \mathrm{~L} 8 \mathrm{D}, n=5)$ or short days $(8 \mathrm{~L} 16 \mathrm{D}, n=4)$. On day 0 the exposure to long days was commenced. B) Differences in the means of plasma prolactin ( $\triangle \mathrm{PRL}$ ) between the lond-day group and short-day group; the mean prolactin value for the short-day group was subtracted from that for the long-day group on each occasion. * $P<0.05,{ }^{* *} P<0.01$.

cyclicity and PRL secretion in the goat. In order to extract the effect of photoperiod on PRL secretion the difference in the mean plasma PRL concentration between the two groups was calculated on each occasion by subtracting the mean PRL value for the short-day group from that for the long-day group and was presented as a function of the time course of long-day treatment. The difference in PRL level between the two groups gradually increased and was significant on days 78-148. On the other hand, the number of goats recurring estrous cycles under long days gradually declined and the estrous cyclicity of this group was completely abolished by day 100 , while the goats kept under short days continued to cycle. In the long-day goats the acyclic period synchronized with the time when plasma levels of PRL 
were significantly higher than the short-day group. The difference in mean PRL levels between the two groups diminished by day 200 when the long-day goats spontaneously resumed estrous cyclicity.

\section{Discussion}

Photoperiod had a profound effect on PRL secretion from the pituitary of female goats; their plasma PRL concentrations showed high level under long days, but remained low under short days. The results agreed with those reported in ewes ${ }^{17}$. As a marked elevation in plasma PRL occurred during the summer period, high ambient temperature was another environmental factor responsible for PRL release, because both in the magnitude and the pattern PRL rise in the summer was indistinguishable between two groups receiving different photoperiodic treatments. On hot days $(>27 \mathrm{C}$ at the time of blood sampling) very high levels of plasma PRL were recorded invariably. TUCKER et al. ${ }^{8)}$ reported that, in prepubertal heifers, serum PRL changed rapidly (within minutes) with the changes in ambient temperature, while the PRL response to the changes in photoperiod was slow, requiring at least a week. In goats and heifers highly significant correlation of serum PRL concentration with ambient temperature $(r=0.806-0.850)$ has been demonstrated ${ }^{5)}$. Changes in ambient temperature therefore would contribute considerably to the annual pattern of PRL secretion in the goats. The high PRL concentrations found in the summer might be concerned with salt retention since a restorative action of PRL on saluretic effect of aldosterone has been shown ${ }^{13)}$.

The diurnal pattern of PRL secretion was strongly linked with photoperiod; high mean values for $24 \mathrm{~h}$ PRL levels was observed under the longer daylength. A nocturnal rise in PRL levels similar to that seen in the goat was reported in rams staying under long days ${ }^{19)}$.

Exposure of goats to long days resulted in an abolition of estrous cyclicity and a simultaneous increase in PRL secretion. Although the reason is unclear, plasma PRL levels declined by day 200 despite of continuous exposure to long days and the goats resumed estrous cyclicity ${ }^{1+)}$. Similar results have been reported in sheep kept outdoor that serum levels of PRL are high throughout seasonal anestrus and fell before the onset of estrous cyclicity in the autumn ${ }^{1)}$.

High concentrations of plasma PRL have been implicated as the cause of lactational anestrus in the $\mathrm{ewe}^{12)}$, and amenorrhea generally occurs in women with pathologi$\mathrm{cal}^{9,11)}$ or lactational ${ }^{10)}$ hyperprolactinemia. Elevated plasma levels of PRL, induced by TRH injection, resulted in suppression of estradiol secretion in the $\mathrm{ewe}^{20)}$. Ovulation in perifused rabbit ovary in vitro could be inhibited by $P R L^{21)}$, suggesting a direct effect of PRL on the ovaries. The pituitary response to $L H R H$ is reduced by $P R L$ in rats $^{22)}$, and the positive feedback effects of estradiol on $\mathrm{LH}$ release was abolished or greatly impaired by high PRL levels in women $^{9)}$ and ewes $^{13)}$. The hypothalamopituitary axis therefore seems another plausible site of PRL action.

While the antigonadotropic effects of PRL have been consistently demonstrated, LAND et $a l .{ }^{23)}$ reported that suppression of $\mathrm{PRL}$ secretion with bromocriptine was unable to restore estrous cycles to ewes in seasonal 
anestrus. Whether accelerated PRL secretion by long days is directly responsible for the arrested ovarian cyclicity of the goat remains to be solved.

\section{Acknowledgements}

We thank Dr. T. Jонке, National Institute of Animal Industry, Ibaraki, for his generous supply of the reagents for prolactin radioimmunoassay. We are grateful to Dr. M. TAKahashi, University of Tokyo, for constructive advices and to $M_{R}$. K. OhmiYa and Mr. Y. Nakamura, Tokyo University of Agriculture and Technology, for their help with the assay.

\section{References}

1) Walton JS, JR MicNeilly, AS McNeilly \& FJ Cunningham: J. Endocr., 75, 127, 1977.

2) Ravault JP: Acta endocr., 83, 720, 1976.

3) Butrle HL: J. Reprod. Fert., 37, 95, 1974.

4) HaRT IC: J. Endocr., 64, 313, 1975.

5) Johke T, K Hodate \& A Kawabata: Bull. Nat. Inst. Anim. Indus., 38, 39, 1982.

6) Pelletier J: J. Reprod. Fert., 35, 143, 1973.

7) Lincoln GA \& RV Short: Rec. Prog. Horm. Res., 36, 1, 1980.

8) Tucker HA \& RP Wettemann: Proc. Soc. Exp. Biol. Med., 151, 623, 1976.
9) Besser GM, L Parke, CRW Edward, IA ForSYтh \& AS MCNeILly: Br. Med. J., 3, 669, 1972.

10) Rolland R, RM Lequin, LA Schellekens \& FH DE Jong: Clin. Endocrinol., 4, 15, 1975.

11) Kredentser JV, CF Hoskins \& JZ Scott: $A m$. J. Obstet. Gynecol., 139, 264, 1981.

12) Kann G \& J Martinet: Nature, 257, 63, 1975.

13) Kann G, J Martinet \& A Schirar: Nature, 264, 465, 1976.

14) Mori $Y, K$ Maeda, T Sawasaki \& Y Kano: Japan. J. Anim. Reprod., 30, 239, 1984.

15) SAKAI $\mathrm{S}, \mathrm{K}$ Конмото \& $\mathrm{T}$ ЈонкE: Endocrinol. Japon., 22, 379, 1975.

16) Јонке T: Endocrinol. Japon., 16, 581, 1969.

17) Worthy K \& W Haresign: J. Reprod. Fert., 69, $41,1983$.

18) Horrobin DF, MS Manku \& PG Burstyn: $J$. Endocr., 56, 343, 1973.

19) Lincoln GA, AS McNeilly \& Cl Cameron: $J$. Reprod. Fert., 52, 305, 1978.

20) McNeilly AS \& DT Batrd: J. Reprod. Fert., 69, 559, 1983.

21) Hamada $Y, S$ Schlaff, Y Kobayashi, R Santulli, KH Wright \& EE Wallach: Nature, 285, 161, 1980.

22) Sмiтн MS: Endocrinology, 102, 114, 1978.

23) Land RB, WR Carr, AS McNeilly \& RD PREECE: J. Reprod. Fert., 59, 73, 1980.

(Received November 21, 1984) 


\title{
ヤギのプロラクチン (PRL) 分泌に対する日長の影響
}

\author{
森 裕司*・前多敬一郎・沢崎 徹・加納康彦 \\ (*東京農工大学家音臨床智殖学教室 東京大学農学部付属牧場)
}

ヤギでは血中 PRL 濃度に著明な季節変動が認められ る。本実験では PRL 分泌に対する光周期の影響を調べ る目的でザーネン種雌ヤギに為的長日 (16L8D) ある いは短日 (8L16D) 条件を負荷し血中 PRL 動態を比較 険討した。日長制御は内因性 PRL 分泌の最も低下する 12 月に開始し約 1 年間継続した。

長日条件下では PRL 分泌は促進され, 長日開始 42 日後には暗期にピークを示す明らかな日周パターンが認 められた。一方，短日条件下では PRL 分泌は抑制され 血中 PRL は低レベルに保たれた。7〜8 月にかけて長短 日の両群で PRL 分泌の著明なえ進が観察されたが, PRL 濃度上昇の程度・バターンのい寸゙れについても両群 間に差が認められないことから夏季高温に起因するもの
と推察された。長日により PRL の血中レベルが上界し 長日・短日群間の差が有意となる時期 (長日開始後 78〜 148 日）は，長日群において性周期が抑制される時期に 一致した。また，長日開始後200日までにはPRL 分泌 に対する促進効果は減衰し短日群の血中レベルとの差は 消失したが，時を同じくして生殖機能に対する年日の抑 制効果も解除され，その結果ヤギは性周期を再開した。

以上の成績から, ヤギの PRL 分泌に対して長日は促 進的に，短日は抑制的にそれぞれ影響することが示され た。また PRL 分必の促進と性周期の抑制が長日条件下 において同時期に観察され，両現象間に何らかの関連の 存在する可能性が示唆された。 